\title{
GROWTH PERFORMANCES AND THEIR IMPACT ON CORN YIELD OF BABY CORN AS AFFECTED BY VARIETIES AND DIFFERENT SOURCES OF NITROGEN FERTILIZER
}

\author{
Md. Humaun Kabira, Md. Delwar Hossaina, Md. Harun Or Rashid ${ }^{a}$, Md. Shahriar Kobirb ${ }^{*}$, Md. Kamrul Hasan ${ }^{a}$ \\ a Department of Agronomy, Bangladesh Agricultural University, Mymensingh-2202, Bangladesh. \\ ${ }^{b}$ Bangladesh Agricultural Research Institute, Gazipur, Bangladesh. \\ *Corresponding Author Email: shahriar1302027@gmail.com
}

This is an open access article distributed under the Creative Commons Attribution License CC BY 4.0, which permits unrestricted use, distribution, and reproduction in any medium, provided the original work is properly cited.

\section{ARTICLE DETAILS}

\section{Article History:}

Received 28 October 2020 Accepted 30 Noember 2020 Available online 10 December 2020

\begin{abstract}
Baby corn is an exhaustive cereal in terms of nutrients absorbance from soil and thus soil become easily loss it's beneficial physical and chemical properties. To maintain soil health during cereal production like baby corn both chemical and organic sources of fertilizers can be used, thus a study was executed at the agronomy field of Bangladesh Agricultural University, Mymensingh in the year of 2017-2018 to find out the growth performances and their impact on corn yield of baby corn as affected by varieties and different sources of nitrogen fertilizer. The experiment was conducted in Randomized Completely Block Design with three replications with two factors where two varieties viz., BARI Sweet corn-1 ( $\left.\mathrm{V}_{1}\right)$ and Baby star $\left(\mathrm{V}_{2}\right)$ acted as Factor $\mathrm{A}$ and five sources of nitrogen fertilizer viz.,100\% recommended $\mathrm{N}$ from urea $\left(\mathrm{N}_{1}\right), 75 \% \mathrm{~N}$ from urea + $25 \% \mathrm{~N}$ from cowdung $\left(\mathrm{N}_{2}\right), 50 \% \mathrm{~N}$ from urea $+50 \% \mathrm{~N}$ from cowdung $\left(\mathrm{N}_{3}\right), 75 \% \mathrm{~N}$ from urea $+25 \% \mathrm{~N}$ from poultry manure $\left(\mathrm{N}_{4}\right), 50 \% \mathrm{~N}$ from urea $+50 \% \mathrm{~N}$ from poultry manure $\left(\mathrm{N}_{5}\right)$ acted as Factor $\mathrm{B}$. The highest plant height $(153.0 \mathrm{~cm})$, number of leaves per plant (7.33), leaf chlorophyll content (SPAD value 38.68), (TDM) (40.60 g plant $\left.{ }^{-1}\right)$, corn yield (3520 kg ha-1) were recorded in the interaction between Baby star when fertilized with $\mathrm{N}_{2}(75 \% \mathrm{~N}$ from urea $+25 \% \mathrm{~N}$ from cowdung). All the growth parameters showed strong positive correlation with corn yield. The highest harvest index $(0.075)$ was observed when BARI Sweet corn1 was cultivated with $\mathrm{N}_{2}(75 \% \mathrm{~N}$ from urea $+25 \% \mathrm{~N}$ from cowdung). Therefore, it may be concluded that for better growth performance and for better corn yield Baby star is the promising baby corn variety when cultivated with $(75 \% \mathrm{~N}$ from urea $+25 \% \mathrm{~N}$ from cowdung) for better growth performances and maximization of baby corn yield.
\end{abstract}

\section{KEYWORDS}

growth performance, organic fertilizer, baby corn, nitrogen source.

\section{INTRODUCTION}

Among the different grain crops Maize (Zea mays) is acted as an important crop in most of the developing countries and it is ranked as $2^{\text {nd }}$ grain crop in Bangladesh after rice (Kobir et al., 2019). For it's various use and efficiency it is $3^{\text {rd }}$ in rank in the world after wheat and rice (Kobir et al., 2020). The average yield of maize is 9.27 ton ha- $^{-1}$ in Bangladesh and in the fiscal year (2018-2019) about 4.7 million MT maize has been produced in Bangladesh from 0.507 million hectares of land (AIS, 2020). Being a C4 plant maize can withstand in adverse climatic condition and can convert large amount of prevails nutrient into food for consumption of human (Lara and Andreo, 2011; Archana and Bai, 2017). At the time of silk emergence when maize entire cob is harvested in raw green form prior fertilization is known as baby corn (Galiant, 1985).

Baby corn is mostly used as vegetables and it contains about $86 \mathrm{mg}$ phosphorus in $100 \mathrm{~g}$ of it's corn where other vegetable commodities contain $17 \mathrm{mg}$ - $57 \mathrm{mg}$ phosphorus in their $100 \mathrm{~g}$ part (Demjanova et al., 2009 ). Baby corn contains potassium: $2-3 \%$, calcium: $0.3-0.5 \%$ protein:
15-18\%, fiber: $3-5 \%$, ascorbic acid: 75-80 mg per $100 \mathrm{~g}$, sugar: $0.016-$ $0.020 \%$ (Das et al., 2008; Thavaprakrasaash et al., 2005). For being ecofriendly, high nutritive value and delicious food item baby corn is becoming popular day by day to the elite as well as middle income people in our society. Fertilizer application greatly affected the yield and quality of baby corn (Lone et al., 2011). Among the essential nutrient of plants nitrogen is the most important element for growth and yield of baby corn (Henrique et al., 2016). Now-a-days people are concern about health and environmental hazard so that organic farming is becoming more popular day by day (Muhammad et al., 2016). Chemical fertilizers have capability to boost the yield but considering environmental issue maintaining organic source of fertilizer is a tool to keep surrounding environment healthy.

Moreover, using chemical fertilizer increase the production cost (Dadarwal, 2008). If we use organic source of fertilizer along with inorganic sources soil can withstand with its healthy nature as organic manure improve the physical, chemical and microbial property of soil (Timsina, 2018). As chemical fertilizer increases production cost, creates

\begin{tabular}{|c|c|c|}
\hline Quick Response Code & & \\
\hline 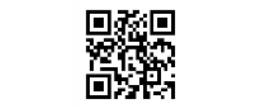 & $\begin{array}{c}\text { Website: } \\
\text { www.actascientificamalaysia.com }\end{array}$ & $\begin{array}{c}\text { DOI: } \\
10.26480 / \text { asm.01.2021.10.14 }\end{array}$ \\
\hline
\end{tabular}


risk of health and environmental hazard then it is necessary to cope up with the practice of organic nitrogen source using. However, organic source of nitrogen can result in slow release of nutrient into the soil that will lead to reduction of yield in corn (Pang and Letey, 2000) so that combination of inorganic and organic nitrogen sources or integrated nutrient management approach have to follow for ensuring sustainable production and soil health (Dawe et al., 2003).

Moreover, integrated chemical and organic fertilizer application improve the soil microbial activity which is responsible for soil health and to increase growth and yield of plants (He and Li, 2004; Saha et al., 2008). To increase the productivity and long-term economic benefit of baby corn production sound fertilization is a must with a suitable variety which will lead the farmers of Bangladesh to uplifts their livelihood and capable them for transforming from subsistence farming to commercial farming which is a must priority of Bangladesh government now a days. Therefore, this study was undertaken to investigate the appropriate combination ratio of organic and inorganic nitrogen fertilizer sources without hampering the potential growth and yield performances.

\section{MATERIAlS AND METHODS}

\section{$2.1 \quad$ Experimental site and soi}

The study was conducted at Bangladesh Agricultural University which was situated in Mymensingh Sadar Upazilla of Mymensingh district in the fiscal year 2017-2018. The experimental site was medium high land in nature and silty- loam in texture having $\mathrm{pH}$ (6.50), organic matter (1.19\%), and total nitrogen of $(0.10 \%)$.

\subsection{Climate}

Sub-tropical climate is prevailed in the experimental site where heavy rainfall and high temperature prevails during (April- September) and low temperature and moderate rainfall prevails during (October- March). Maximum temperature, minimum temperature, rainfall and humidity during the study period have been presented in (Table 1)

Table 1: Rainfall, maximum tem, minimum tem, humidity during

\begin{tabular}{|l|c|c|c|c|}
\multicolumn{5}{|c|}{ cropping season } \\
\hline Parameter/Month & Nov-17 & Dec-17 & Jan-18 & Feb-18 \\
\hline Rainfall $(\mathrm{mm})$ & 25.1 & 33.7 & 0 & 0 \\
\hline Max tem $\left({ }^{\circ} \mathrm{c}\right)$ & 38.5 & 26.8 & 24.5 & 24.45 \\
\hline Min tem $\left({ }^{\circ} \mathrm{c}\right)$ & 18.4 & 15.9 & 10.55 & 14.9 \\
\hline Humidity $(\%)$ & 81.8 & 84.8 & 83.85 & 71.75 \\
\hline
\end{tabular}

\subsection{Planting material}

The seeds of two cultivars namely BARI Sweet corn-1 which was released by Bangladesh Agricultural Research Institute was collected from BARI, Gazipur and another one namely Baby star was collected from local seed market of Mymensingh district.

\subsection{Experimental design, treatment and layout}

The experiment was conducted in randomized completely block design with two factor treatment with three replications. In factor A two varieties of corn was used and in factor B five different sources of nitrogen fertilizer was used as treatments in this experiment. In factor $A$ two varieties viz., BARI Sweet corn- $1\left(\mathrm{~V}_{1}\right)$ and Baby star $\left(\mathrm{V}_{2}\right)$ was used as treatments and in factor B five different sources of nitrogen fertilizer viz.,100\% recommended $\mathrm{N}$ from urea $\left(\mathrm{N}_{1}\right), 75 \% \mathrm{~N}$ from urea $+25 \% \mathrm{~N}$ from cowdung $\left(\mathrm{N}_{2}\right), 50 \% \mathrm{~N}$ from urea $+50 \% \mathrm{~N}$ from cowdung $\left(\mathrm{N}_{3}\right), 75 \% \mathrm{~N}$ from urea + $25 \% \mathrm{~N}$ from poultry manure $\left(\mathrm{N}_{4}\right), 50 \% \mathrm{~N}$ from urea $+50 \% \mathrm{~N}$ from poultry manure $\left(\mathrm{N}_{5}\right)$ was used as treatments. The recommended fertilizer dose per ha for baby corn is Urea: $300 \mathrm{~kg}$, TSP: $150 \mathrm{~kg}$, MoP: $100 \mathrm{~kg}$ (Azad et al., 2019). Unit plot size was ( $2.5 \mathrm{~m} \mathrm{X} 2 \mathrm{~m}$ ) and each block was consisted by ten plots of $5 \mathrm{~m}^{2}$. Thus, a total of $30(5 \times 2 \times 3)$ plots were handled in this experiment.

\subsection{Crop husbandry}

The land was ploughed for three times with tractor drawn mould-board plough. Before sowing of planting materials cowdung and poultry manure as per treatments, full dose of recommended TSP along with MoP and one third of Urea as per treatment were incorporated with soil of each plot. The remaining $2 / 3$ Urea was applied in two equal portions at 15 days after sowing and 35 days after sowing. Planting material was sown in recommended dose of $20 \mathrm{~kg} \mathrm{ha}^{-1}$. Different intercultural operations like thinning, gap filling, irrigation, weeding, disease and insect controlling, detasseling and so on were practiced when needed. After 2-3 days of silk emergence green raw cobs were collected. BARI Sweet corn- 1 and Baby star was harvested on 94 days after sowing and 90 days after sowing, respectively.

\subsection{Collection of experimental data and statistical analysis}

Five plants in each plot were tagged and in 30 DAS, 50 DAS, 70 DAS and in 90 DAS data on plant height $(\mathrm{cm})$, number of leaves per plant, Chlorophyll content (spad value), total dry matter (g plant ${ }^{-1}$ ) were recorded. In harvest as in 90 DAS baby corn yield $\left(\mathrm{kg} \mathrm{ha}^{-1}\right)$ data were collected and then harvest index was calculated according to (Huhn, 1990). After then all collected data were tabulated in Microsoft excel and analysis of variance was done by a statistical software M-STATC and mean separation was done by Duncan's Multiple Range Test according to (Gomez and Gomez, 1984). Correlation-co-efficient and regression equation was measured by using Microsoft excel program.

\section{Results}

\subsection{Effect of varieties}

Results revealed that plant height was significantly influenced due to variety at all the DAS. The highest plant height $(148.27 \mathrm{~cm})$ was recorded in Baby star at 90 DAS which showed superiority in plant heights followed by BARI sweet corn-1 $(141.33 \mathrm{~cm})$ at the same DAS (Figure 1/A). Significant differences were observed for producing number of leaves plant $^{-1}$ due to varieties at all DAS except 90 DAS. The highest number of leaves plant ${ }^{-1}$ (10.93) was recorded in Baby star at 90 DAS. The lowest number of leaves plant ${ }^{-1}$ (10.73) was found in BARI sweet corn-1 at 90 DAS (Figure 1/B). The chlorophyll content of baby corn was significantly affected by variety at 70 and 90 DAS. At 90 DAS, the highest chlorophyll content (37.78) was observed in treatment Baby star and the lowest chlorophyll content (36.46) was obtained from BARI Sweet corn-1 (Figure $1 / C)$. The effect of variety on dry matter production was statistically significant at all sampling dates. At $90 \mathrm{DAS}$, the highest TDM (32.37 g plant $\left.{ }^{1}\right)$ was recorded in Baby star and the lowest one (29.30 g plant $\left.^{-1}\right)$ was recorded in BARI sweet corn-1 (Figure 1/D). The baby corn yield showed significant variation between the varieties. The maximum corn yield was found in Baby star (2910 kg ha-1) and minimum in BARI sweet corn-1 (2440 kg ha-1) (Figure 2). Harvest index showed significance variation between the two varieties. BARI sweet corn-1 showed highest HI (0.067) (Figure 3).
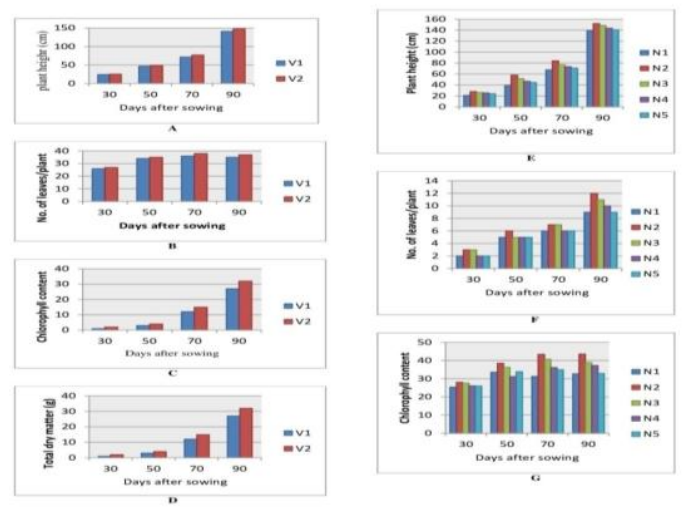

Figure 1: Illustration: A: Effect of varieties on plant height of baby corn; $B$ Effect of varieties on No. of leaves/plant of baby corn; C: Effect of varieties on chlorophyll content (spad value) of baby corn; D: Effect of varieties on total dry matter (g) of baby corn; E: Effect of different sources of nitrogen on plant height of baby corn; F: Effect of different sources of nitrogen on No. of leaves/plant of baby corn; G: Effect of different sources of nitrogen on chlorophyll content (spad value) of baby corn.

( $\mathrm{V}_{1}=$ BARI sweet corn $-1, \mathrm{~V}_{2}=$ Baby star, $\mathrm{N}_{1}=(100 \%$ urea $-\mathrm{N}), \mathrm{N}_{2}=(75 \%$ urea $-\mathrm{N}+25 \% \mathrm{CD}-\mathrm{N}), \mathrm{N} 3=(50 \%$ urea $-\mathrm{N}+50 \% \mathrm{CD}-\mathrm{N}), \mathrm{N}_{4}=(75 \%$ urea $-\mathrm{N}+25 \% \mathrm{PM}-\mathrm{N}), \mathrm{N}_{5}=(50 \%$ urea $-\mathrm{N}+50 \% \mathrm{PM}-\mathrm{N})$. 


\subsection{Effect of different sources of nitrogen fertilizer}

Plant height was significantly influenced by nitrogen fertilizer sources irrespective of growth stages. It was found that treatment $\mathrm{N}_{2}(75 \%$ urea $\mathrm{N}+25 \% \mathrm{CD}-\mathrm{N})$ produced the highest plant height $(152.0 \mathrm{~cm})$ at $90 \mathrm{DAS}$. The shortest plant $(139.2 \mathrm{~cm})$ was obtained from treatment $\mathrm{N}_{1}(100 \%$ urea - N) at 90 DAS (Figure 1/E). The results showed that the number of leaves per plant differed significantly at all the DAS due to different nitrogen sources. The results showed that $\mathrm{N}_{2}(75 \%$ urea $-\mathrm{N}+25 \% \mathrm{CD}-\mathrm{N})$ produced the highest number of leaves plant ${ }^{-1}(11.33)$ and the treatment $\mathrm{N}_{1}(100 \%$ urea - N) produced the lowest number of leaves plant ${ }^{-1}(10.33)$ at $90 \mathrm{DAS}$ (Figure 1/F). The chlorophyll content of baby corn was significantly affected by nitrogen fertilizer sources by all DAS. The highest chlorophyll content (43.46) was observed in treatment $\mathrm{N}_{2}$ (75\% urea - N + 25\% CD$\mathrm{N})$ and the lowest chlorophyll content (31.33) was obtained from $\mathrm{N} 1$ $(100 \%$ urea - N) treatment at 90 DAS (Figure 1/G). Significant effect of nitrogen fertilizer sources was found on total dry matter production. At 90 (harvesting) DAS highest dry matter (38.72 g plant $^{-1}$ ) recorded in $\mathrm{N}_{2}(75 \%$ $\mathrm{N}$ from urea $+25 \% \mathrm{~N}$ though cowdung). The lowest dry matter production was recorded $\left(24.07\right.$ g plant $\left.^{-1}\right)$ in treatment $\mathrm{N}_{1}(100 \%$ recommended $\mathrm{N}$ from urea) (Figure $4 / \mathrm{H}$ ). The baby corn yield showed significance variation for different sources of nitrogen fertilizer. The highest corn yield (3180 kg ha $\left.{ }^{-1}\right)$ was recorded in $\mathrm{N}_{2}(75 \% \mathrm{~N}$ from urea $+25 \% \mathrm{~N}$ from cowdung) and the lowest corn yield (2340 kg ha-1) was recorded in $\mathrm{N}_{1}$ (100\% recommended $\mathrm{N}$ from urea) (Figure 2). Different sources of nitrogen fertilizer showed significant variation for harvest index. The highest $\mathrm{HI}(0.069)$ was recorded in $\mathrm{N}_{2}(75 \% \mathrm{~N}$ from urea $+25 \% \mathrm{~N}$ from cowdung) treatment (Figure 3).

varieties, different sources of nitrogen fertilizers and their interaction

Figure 2: Effect of varieties, different sources of nitrogen fertilizers and their interaction on corn yield $(\mathrm{kg} / \mathrm{ha})$ of baby corn

$\left(\mathrm{V}_{1}=\right.$ BARI sweet corn $-1, \mathrm{~V}_{2}=$ Baby star, $\mathrm{N}_{1}=(100 \%$ urea $-\mathrm{N}), \mathrm{N}_{2}=(75 \%$ urea $-\mathrm{N}+25 \% \mathrm{CD}-\mathrm{N}), \mathrm{N} 3=(50 \%$ urea $-\mathrm{N}+50 \% \mathrm{CD}-\mathrm{N}), \mathrm{N}_{4}=(75 \%$ urea $-N+25 \% P M-N), N_{5}=(50 \%$ urea $-N+50 \% P M-N)$.

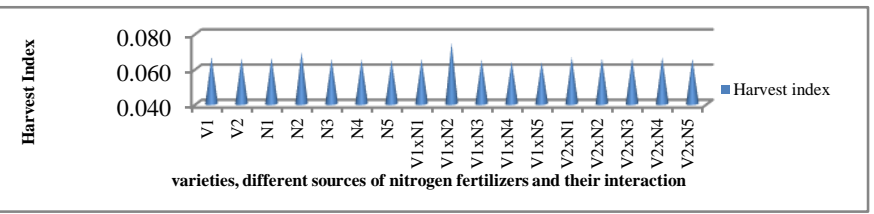

Figure 3: Effect of varieties, different sources of nitrogen fertilizers and their interaction on Harvest index of baby corn

( $\mathrm{V}_{1}=$ BARI sweet corn $-1, \mathrm{~V}_{2}=$ Baby star, $\mathrm{N}_{1}=(100 \%$ urea $-\mathrm{N}), \mathrm{N}_{2}=(75 \%$ urea $-\mathrm{N}+25 \% \mathrm{CD}-\mathrm{N}), \mathrm{N} 3=(50 \%$ urea $-\mathrm{N}+50 \% \mathrm{CD}-\mathrm{N}), \mathrm{N}_{4}=(75 \%$ urea $-\mathrm{N}+25 \% \mathrm{PM}-\mathrm{N}), \mathrm{N}_{5}=(50 \%$ urea $-\mathrm{N}+50 \% \mathrm{PM}-\mathrm{N})$.

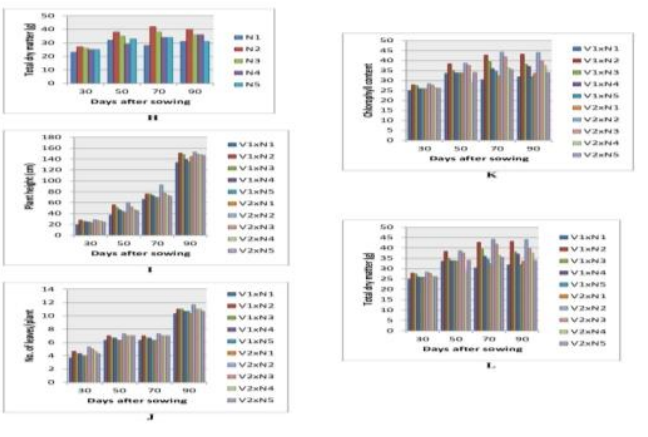

Figure 4: Illustration: $\mathrm{H}$ : Effect of different sources of nitrogen on total dry matter (g) of baby corn; I: Interaction effect of varieties and different sources of nitrogen on plant height $(\mathrm{cm})$ of baby corn; J: Interaction effect of varieties and different sources of nitrogen on No. of leaves/plant of baby corn; K: Interaction effect of varieties and different sources of nitrogen on chlorophyll content (spad value) of baby corn; L: Interaction effect of varieties and different sources of nitrogen on total dry matter (g) of baby corn
$\left(\mathrm{V}_{1}=\right.$ BARI sweet corn $-1, \mathrm{~V}_{2}=$ Baby star, $\mathrm{N}_{1}=(100 \%$ urea $-\mathrm{N}), \mathrm{N}_{2}=(75 \%$ urea $-\mathrm{N}+25 \% \mathrm{CD}-\mathrm{N}), \mathrm{N} 3=(50 \%$ urea $-\mathrm{N}+50 \% \mathrm{CD}-\mathrm{N}), \mathrm{N}_{4}=(75 \%$ urea $-\mathrm{N}+25 \% \mathrm{PM}-\mathrm{N}), \mathrm{N}_{5}=(50 \%$ urea $-\mathrm{N}+50 \% \mathrm{PM}-\mathrm{N})$.

3.3 Interaction effect of varieties and different sources of nitrogen fertilizer

Plant height was significantly influenced by the interaction of variety and nitrogen fertilizer sources at 30 to 90 DAS. It was observed that the tallest plant stature $(153.0 \mathrm{~cm})$ was at 90 DAS in Baby star $\times(75 \% \mathrm{~N}$ from urea + $25 \% \mathrm{~N}$ from cowdung) and the shortest plant stature $(133.7 \mathrm{~cm})$ was in BARI sweet corn- $1 \times 100 \%$ recommended $\mathrm{N}$ from urea (Figure $4 / \mathrm{I}$ ). In case of number of leaves per plant interaction effect showed non-significant variation in all growth stages except 70 DAS (Figure 4/J). The interaction effect showed non-significant variation at all growth stages except 50 DAS for chlorophyll content (Figure $4 / \mathrm{K}$ ). The results indicated that there was significant interaction effect between variety and nitrogen fertilizer sources at all DAS except 30 DAS for dry matter production. At 90 (harvesting) DAS the highest dry matter production $\left(40.60 \mathrm{~g} \mathrm{plant}^{-1}\right)$ was recorded in $\mathrm{V}_{2} \mathrm{~N}_{2}$ (Babystar $\times 75 \% \mathrm{~N}$ from urea $+25 \% \mathrm{~N}$ from cowdung) and minimum (21.13 g plant $\left.^{-1}\right)$ was recorded in $\mathrm{V}_{1} \mathrm{~N}_{1}$ (BARI sweet corn- 1 $\times 100 \%$ recommended $\mathrm{N}$ from urea) (Figure $4 / \mathrm{L}$ ). Baby corn yield showed significant variation for the interaction of varieties and different sources of nitrogen fertilizer. The highest (3520 $\left.\mathrm{kg} \mathrm{ha}^{-1}\right)$ corn yield was found in Baby star fertilized with $\mathrm{N}_{2}(75 \% \mathrm{~N}$ from urea $+25 \% \mathrm{~N}$ from cowdung) and the minimum corn yield (1890 $\left.\mathrm{kg} \mathrm{ha}^{-1}\right)$ was obtained in BARI sweet corn- 1 with $\mathrm{N}_{1}(100 \%$ recommended $\mathrm{N}$ from urea) (Figure 2). Interaction effect showed significant variation for harvest index of baby corn. The highest HI (0.075) was observed when BARI Sweet corn-1 was cultivated with $\mathrm{N}_{2}(75 \% \mathrm{~N}$ from urea $+25 \% \mathrm{~N}$ from cowdung) treatment and the lowest HI (0.064) was observed when BARI Sweet corn-1 was cultivated with $\mathrm{N}_{5}$ (50\% recommended nitrogen from Urea $+50 \% \mathrm{~N}$ from PM) (Figure 3).

\subsection{Correlation-co-efficient and regression equation}

All the parameters like plant height $(\mathrm{r}=0.85)$, number of leaves per plant $(\mathrm{r}=0.75)$, chlorophyll content $(\mathrm{r}=0.70)$ and total dry matter $(\mathrm{r}=0.75)$ have strong positive correlation with corn yield of baby corn (Table 02 ).

\begin{tabular}{|l|c|c|c|}
\hline \multicolumn{4}{|c|}{ Table 2: Correlation -co- efficient and regression equation for growth } \\
parameters with yield of baby corn
\end{tabular}

\section{DisCUSSIONS}

From the results section we can see that the growth parameters like plant height, number of leaves per plant, chlorophyll content and total dry matter content is varied in respect of variety to variety. The leaf production was increased with the advancement of time from 30 to 90 DAS. Results showed that the total dry matter accumulation was increased with time and reached at the peak at 90 DAS. Corn yield of Baby star was around 19\% greater than BARI sweet corn-1. From the above-mentioned points, it is clear that there exist strong differences between two varieties like BARI Sweet corn-1 and Baby star for growth performance and corn yield. A studied five genotypes of baby corn and found one variety performed better in physical characteristics (Sharma et al., 2009). This finding was declared that different varieties perform differently due to genetic variation among the cultivars. Some researchers observed that dry matter production (TDM) significantly influenced by the varieties (Asaduzzaman et al., 2014). Present research findings also corroborate with that previous study.

In our present study plant height of baby corn was differed due to different nitrogen sources. The number of leaves plant ${ }^{-1}$ increased with increasing days after transplanting due to application of different levels of fertilizers and manures. The highest number of leaves plant ${ }^{-1}$ occurred due to the absorption of more nutrient, moisture and also for availability of more sunlight. The lowest number of leaves plant ${ }^{-1}$ occurred due to lack of 
proper organic sources. Chlorophyll content and total dry matter also become improved when appropriate combination of organic and inorganic sources of nitrogen fertilizer were applied. Similar results were also reported that is use of organic and inorganic fertilizer increased the total dry matter production of baby corn (Hussain, 2014). Organic fertilizer application along with inorganic sources can improve the baby corn plant growth parameters like plant height, leaf area index, number of leaves per plant, absolute growth rate and dry matter production that is revealed by (Reddy et al., 2009; Aravinth et al., 2011; Meneghetti et al., 2012). Corn yield from $\mathrm{N}_{2}$ (75\% $\mathrm{N}$ from urea $+25 \% \mathrm{~N}$ from cowdung) was around $35 \%$ greater than $\mathrm{N}_{1}(100 \%$ recommended $\mathrm{N}$ from urea)

When variety Baby star was fertilized with $\mathrm{N}_{2}(75 \% \mathrm{~N}$ from urea $+25 \% \mathrm{~N}$ from cowdung) treatment then all the parameters showed better result in contrast with the recommended mineral fertilization treatment. It is due to as combined organic and inorganic fertilizer can increase the enzyme activity and can increase the microbial activity in the soil (He and Li, 2004; Saha et al., 2008). Our present study also showed more or less similar findings. A group revealed that inorganic nitrogen sources can maximize the baby corn yield but it is statistically similar when application of nitrogen fertilizer combined with $25 \%$ from farm yard manure or from sheep manure or from poultry manure and $75 \%$ from inorganic sources (Kumar et al., 2009). A group researcher revealed that the combination of $75 \% \mathrm{~N}$ through urea $+25 \% \mathrm{~N}$ through FYM $+40 \mathrm{~cm} \times 15 \mathrm{~cm}$ spacing emerged superior over all other treatment (Neupane et al., 2011). However, our present experiment revealed that yield contributing characters of Baby corn showed better result with the application of $\mathrm{N}$ fertilizer as $75 \%$ from inorganic sources and $25 \%$ from cowdung which is similar to above mentioned previous literature.

\section{CONCLUSION}

According to the results and discussions chapter variety Baby star perform better over BARI Sweet corn-1 in all the growth parameters and in corn yield. ( $75 \% \mathrm{~N}$ from urea $+25 \% \mathrm{~N}$ from cowdung) treatment showed better performance in all the parameters among different sources of nitrogen fertilizer. The interaction of Baby star and $(75 \% \mathrm{~N}$ from urea $+25 \% \mathrm{~N}$ from cowdung) performed as the best treatment among all the interactions. So, to get better growth performance as well as for better corn yield $(75 \% \mathrm{~N}$ from urea $+25 \% \mathrm{~N}$ from cowdung) with variety Baby star practice should be followed.

\section{ACKNOWLEDGMENT}

The study was financially assisted by National Science and Technology fellowship under Ministry of Science and Technology of government of the people's republic of Bangladesh. Respected teachers and staffs of Bangladesh agricultural University have highly assisted during execution of the study by sharing their expertise and dedication.

\section{REFERENCES}

AIS. 2020. Agricultural Information Services.Department of Agricultural Extension, Bangladesh. Production and area of field crops, Pp.13

Aravinth, V., Kuppuswamy, G., Ganapathy, M., 2011. Growth and yield of baby corn (Zea mays L.) as influenced by intercropping, planting geometry and fertilizer levels. Indian Journal of Agricultural Sciences, 81 (9), Pp. 875-877.

Archana, C.R., and Bai, E.K.L., 2017. Influence of varieties and spacing on yield of dual purpose baby corn (Zea mays L.) in summer rice fallows of Kerala. Journal of Tropical Agriculture, 54, Pp.190.

Asaduzzaman, M., Biswas, M., Islam, N., Rahman, M.M., Begum, R., Sarkar, M.A.R., 2014. Variety and N-fertilizer rate influence the growth, yield and yield parameters of baby corn (Zea mays L.). Journal of Agricultural Science, 6 (3), Pp. 12-23.

Azad, A.K., Wahab, A., Saha, M.G., Nesa, Z., Rahman, M.L., Rahman, H.H., Amin, L., 2019. Krishi Projukti Hatboi (Handbook on Agro-technology), $8^{\text {th }}$ edition. Bangladesh Agricultural Research Institute, Gazipur-1701, Bangladesh, Pp.380.http://www.bari.gov.bd

Dadarwal, R., 2008. Integrated nutrient management in baby corn (Zea mays L.). Udaipur: Maharana Pratap University of Agriculture and Technology.

Das, S., Ghosh, G., Kaleem, M.D., Bahadur, V., 2008. Effect of different levels of nitrogen and crop geometry on the growth, yield and quality of baby corn (Zea mays L.) cv.'golden baby'. In: International Symposium on the Socio-Economic Impact of Modern Vegetable Production Technology in Tropical Asia 809. Chiang Mai, Thailand, Pp. 161-166.

Dawe, D., Dobermann, A., Ladha, J.K., Yadav, R.L., Bao, L., Gupta, R.K., Lal, P., Panaullah, G., Sariam, O., Singh, Y., 2003. Do organic amendments improve yield trends and profitability in intensive rice systems? Field Crops Research, 83 (191), Pp. 213

Demjanova, E.M., Macak, S., Dalovic, T., Smatana, J., 2009. Effects of tillage systems and crop rotation on weed populations, density, diversity and weed biomass in maize. Agronomy Research , 7 (2), Pp. 785- 792.

Galinat, W.C., 1985. Whole ear baby corn, a new way to eat corn. Proc. Northeast Corn Improvement Conf., 40, Pp.22-27.

Gomez, K.A., Gomez, A.A., 1984. Statistical procedure for agricultura research. John Wiley and Sons, New York, second edition, Pp. 680.

He, Y., Li, R., 2004. Effect of the organo-inorgano-mixed fertilizer application on sugarcane yield and soil enzymatic activity. Sugar Crops China, 4, Pp. 36-38.

Henrique, D.G., Carvalho, I., Nardino, M., Szareski, V., Morgan, D.S., Corazza da Rosa, T., Follmann, D., Andrade Monteiro, M., Basso, J., Pedó, T., Tiago, Z., 2016. Importance of nitrogen in maize production. International journal of Current Research, 8, Pp. 36629-36634.

Huhn, M., 1990. Comments on the calculation of mean Harvest Indices. J. Agronomy \& Crop science, 165, Pp. 86-93.

Hussain, A., 2014. Effect of different combinations of organic and inorganic nutrients on productivity and profitability of baby corn varieties in Kashmir Valley. Ph.D. thesis, Sher-e-Kashmir University of Agricultural Sciences \& Technology of Kashmir, Division of Agronomy, Shalimar Campus, Srinagar, Pp. 190025.

Kobir, M.S., Rahman, M.R., Islam, A.K.M.M., Paul, S., Islam, M.M., Farid, M.N., Hajong, P., 2019. Yield performance of some maize varieties as influenced by irrigation management at different growth stages. Res. Agric. Livest. Fish., 6 (1), Pp. 57-67.

Kobir, M.S., Rahman, M.R., Islam, A.K.M.M., 2020. Dry matter partitioning of maize plant as affected by water management at different growth stages. Tropical Agrobiodiversity, 1 (1), Pp.31-36.

Lara, M.V., and Andreo, C.S., 2011. C4 plants adaptation to high levels of CO2 and to drought environments. In: Abiotic Stress in PlantsMechanisms and Adaptations in A Shanker (Ed), Abiotic stress in plants - mechanisms and adaptations. Croatia: InTech, Pp. 415-428.

Lone, A.A., Allai, B.A., Nehvi, F.A., 2013. Growth, yield and economics of baby corn (Zea mays L.) as influenced by Integrated Nutrient Management (INM) practices. African Journal of Agricultural Research, 8, Pp. 4537-4540.

Meneghetti, A.M., Nobrega, L.H.P., Sampaio, S.C., Ferques, R.G., 2012 Revista Brasileira de Agricola e Ambiental, 16 (11), Pp. 1198-1205.

Muhammad, S., Fathelrahman, E., Tasbih Ullah, R.U., 2016. The significance of consumer's awareness about organic food products in the United Arab Emirates. Sustainability, 8, Pp. 833.

Neupane, M.P., Singh, R.K., Kumar, R., Kumari, A., 2011. Response of Baby Corn (Zea mays L.) to Nitrogen Sources and Row Spacing. Environment \& Ecology, 29 (3), Pp. 1176-1179.

Pang, X.P., Letey, J., 2000. Organic farming challenge of timing nitrogen availability to crop nitrogen requirements. Soil Science Society of America Journal, 64, Pp. 247-253.

Reddy, V.B., Madhavi, G.B., Reddy, V.C., Reddy, K.G., Reddy, M.C.S., 2009 Intercropping of baby corn (Zea mays L.) with legumes and cover crops. Agricultural Science Digest, 29 (4), Pp. 260-263.

Saha, S., Prakash, V., Kundu, S., Kumar, N., Mina, B.L., 2008. Soil enzymatic activity as affected by long-term application of farmyard manure and 
mineral fertilizer under a rainfed soybean-wheat system in N-W Himalaya. Eur. J. Soil Biol., 44, Pp. 309-315.

Sharma, R.K., Saxena, V.K., Malhi, N.S., Grewal, M.S., 2009. Identification of suitable genotypes for baby corn. Journal of Research Punjab Agricultural University, 39 (4), Pp. 479-481.

Thavaprakaash, N., Velayudham, K., Muthukumar, V.B., 2005. Effect of crop geometry, intercropping systems and integrated nutrient management practices on productivity of baby corn (Zea mays L.) based intercropping systems. Research Journal of Agricultural and Biological Sciences, 1, Pp. 295-302.

Timsina, J., 2018. Can Organic Sources of Nutrients Increase Crop Yields to Meet Global Food Demand? Agronomy, 8, Pp. 214.

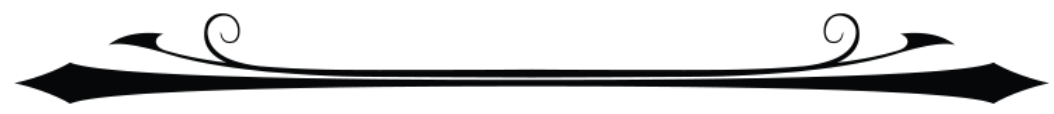

